Rev. Int. Contam. Ambie. 35 (1) 35-46, 2019

DOI: $10.20937 /$ RICA.2019.35.01.03

\title{
WATER POVERTY INDEX IN ARID ZONES: THE BARRIL AQUIFER, SANTO DOMINGO, SAN LUIS POTOSÍ, MEXICO
}

\author{
Briseida LÓPEZ-ÁLVAREZ ${ }^{1 *}$, Zenón RIZO-FERNÁNDEZ², José Alfredo RAMOS-LEAL ${ }^{2}$, \\ Janete MORÁN-RAMÍREZ ${ }^{3}$ and Óscar Guadalupe ALMANZA-TOVAR ${ }^{2}$
}

\author{
${ }^{1}$ El Colegio de San Luis, Parque de Macul 155, Colinas del Parque, 78294 San Luis Potosí, S.L.P., México \\ ${ }^{2}$ Instituto Potosino de Investigación Científica y Tecnológica, Camino a la Presa San José 2055, Col. Lomas, \\ 4a sección, 78216 San Luis Potosí, S.L.P., México \\ ${ }^{3}$ Catedra CONACYT-UNAM Geofísica, Circuito de la Investigación Científica s/n, Ciudad Universitaria, 04150 \\ Coyoacán, Ciudad de México \\ *Corresponding author: briseida.lopez@colsan.edu.mx
}

(Received August 2017; accepted May 2018)

Key words: Potosino highland, water resources, human development, water quality, soil saline

\begin{abstract}
In Mexico, $73.7 \%$ of the territory is made up of arid and semi-arid zones where groundwater is the main source of supply for the population's various activities. The municipality of Santo Domingo is in such a case, with a predominantly dry climate and a $99 \%$ dependence on groundwater of the Barril aquifer. Climatic, geological, and hydrological factors have conditioned not only access to water in quantity and quality, but also the type of vegetation and productive activities. Calculating a water poverty index (WPI) allows the evaluation of water poverty taking into account both physical and socioeconomic factors related to the availability of water. The WPI results from the weighted sum of six components: resources, access, use, capacity, quality, and environment, on an evaluation scale of 0 to 100 . The objective of this work was to estimate the WPI in a region with extreme climatic conditions, scarce vegetation, contamination problems in soils and water such as those in Santo Domingo, obtaining a score of 27 points.
\end{abstract}

Palabras clave: altiplano potosino, recursos hídricos, desarrollo humano, calidad del agua, suelos salinos

\section{RESUMEN}

En México, el $73.7 \%$ del territorio está constituido por zonas áridas y semiáridas donde el agua subterránea es la fuente principal de abastecimiento para las diversas actividades de la población. En esta condición se encuentra el municipio de Santo Domingo, con un clima predominantemente seco y una dependencia del $99 \%$ del agua subterránea del acuífero El Barril. Las condiciones climáticas, geológicas e hidrológicas han condicionado no sólo el acceso al agua en cantidad y calidad, sino también el tipo de vegetación y las actividades productivas. El cálculo del índice de pobreza de agua (IPA) permite evaluar esta circunstancia tomando en cuenta factores tanto físicos como socioeconómicos relacionados con la disponibilidad de agua. El IPA resulta de la suma ponderada de seis componentes: recursos, acceso, uso, capacidad, calidad y medio ambiente en una escala de evaluación de 0 a 100. El objetivo de este trabajo fue estimar el IPA de una región con condiciones climáticas extremas, vegetación escasa, y problemas de contaminación en suelos y agua, como Santo Domingo, que obtuvo una puntuación de 27 puntos. 


\section{INTRODUCTION}

In Mexico, $73.7 \%$ of the territory is made up of arid and semi-arid zones (SAGARPA 2013). It is in these areas that groundwater is the main source of supply for the population's various activities in regions characterized by an extremely dry climate. The population of the municipality of Santo Domingo (SD) practically depends on the groundwater of the Barril aquifer (B), which has a deficit in water availability (CONAGUA 2015).

The BA's groundwater has been studied to a limited extent. The last revision of the groundwater descents was carried out in 1997, where a reduction of the order of $3 \mathrm{~m}$ on average was reported from 1996 to 1997 (INEGI 2007). However, there were significant declines of $6 \mathrm{~m}$ on average from 1977 to 1981 (CONAGUA 2002). Other facts to consider are the number of existing uses. In 1977, there were 471 sources of water supply, 192 wells and 279 dugwells. In 1981 there were 512 sources, of which 229 were wells and 283 dugwells. Of the sources, $96 \%$ are intended for agricultural use (CONAGUA 2015). This situation is an indicator of the groundwater's importance to economic activities in the region.
The BA is located in the northwestern part of the state of San Luis Potosí within hydrological region no. 37, El Salado. It has an endorheic drainage basin and intermittent river currents.

The climatic conditions are extreme, as the prevailing climate is warm and dry with an average temperature of $17^{\circ} \mathrm{C}$ (average minimum temperature of $13.5^{\circ} \mathrm{C}$ and average maximum of $20.35^{\circ} \mathrm{C}$ ), annual average precipitation between 200 and $350 \mathrm{~mm}$, and potential evaporation that has been estimated at 1900 mm (Pineda-Martínez et al. 2007).

There are no significant surface currents or bodies of water that can be permanently harvested for human consumption or agricultural irrigation (Fig. 1). There are intermittent currents and bodies of saline water (El Perdido, El Muerto, and El Lobo lakes), which, due to their shallow depth and evaporation, favor the formation of salt deposits.

Thus, climatic, geological, and hydrological conditions have determined the type of vegetation (scrub and pasture) and productive activities (Fig. 2). The SD municipality covers $4353.9 \mathrm{~km}^{2}$, of which $76.5 \%$ $\left(3330 \mathrm{~km}^{2}\right)$ area is not suitable for agricultural use (INEGI 2009). However, $67 \%$ of its population (12043 inhabitatnts) is engaged in agricultural activities.

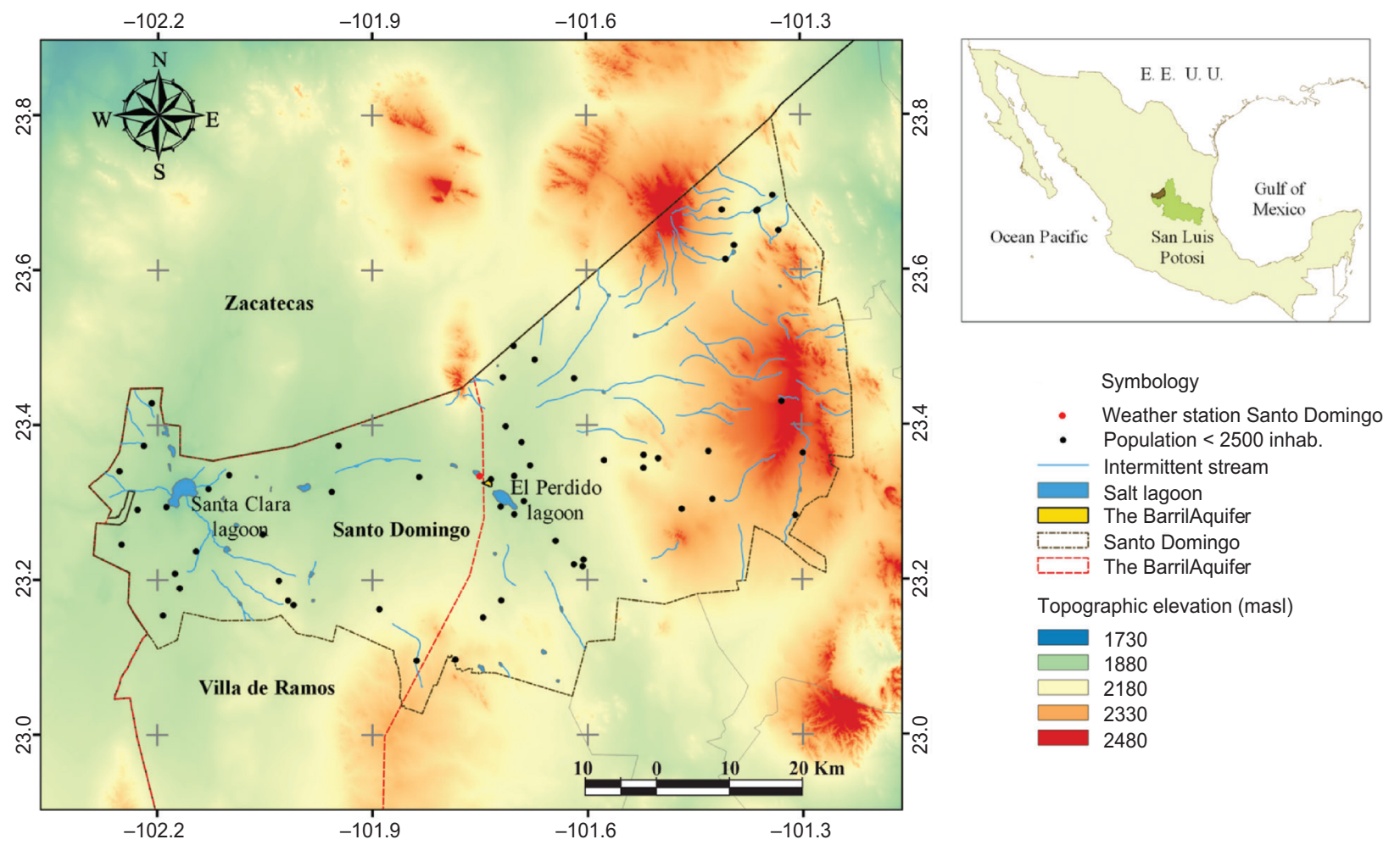

Fig. 1. Location of the Barril Aquifer in the municipality of Santo Domingo, San Luis Potosí, Mexico 

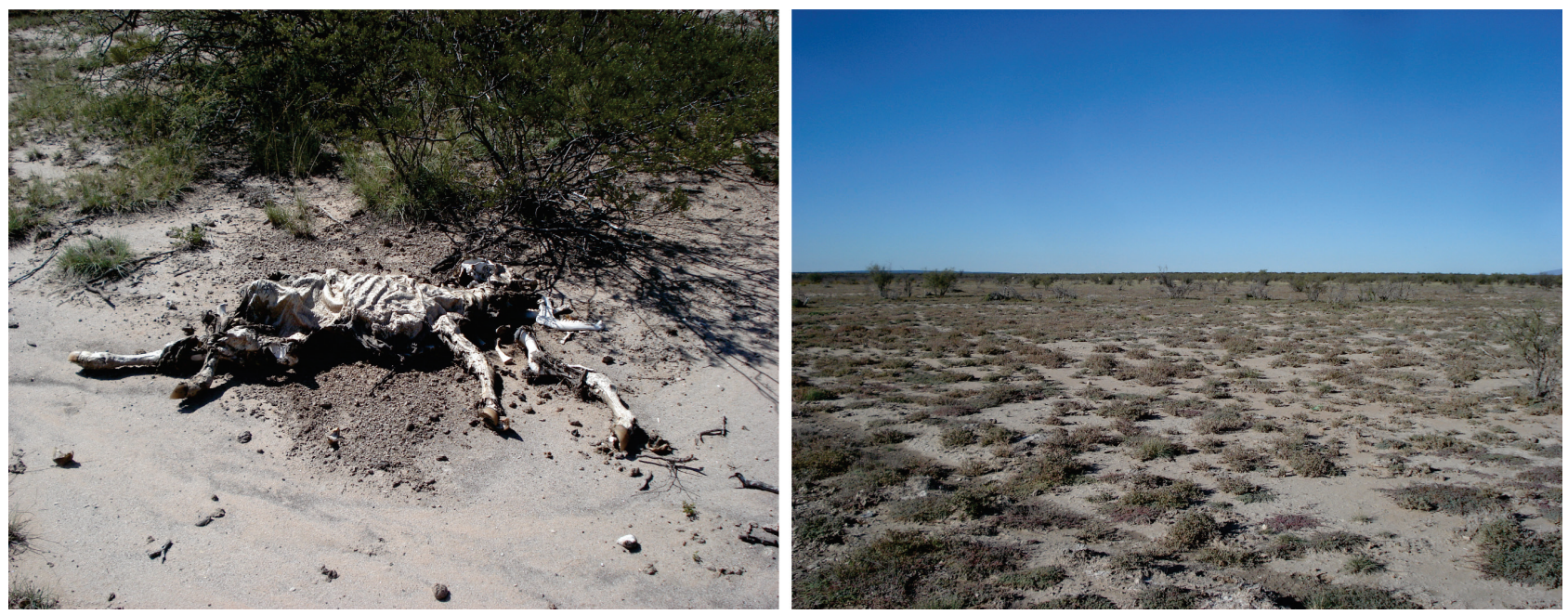

Fig. 2. Typical vegetation of the study area

A tool to assess the availability of water in a population is the water poverty index (WPI), designed to contribute to effective water management (Sullivan et al. 2003). This index relates poverty, social marginalization, environmental integrity, and health in a region and takes into consideration physical and socioeconomic aspects related to water availability (Lawrence et al. 2002).

The original methodology considers five components: water resources, access, capacity, use, and the environment, evaluated on a scale of 0 to 100 . A score of 100 indicates that the assessed region has no availability problems and 0 shows that water availability is zero based on the five components.

This methodology has been modified in the San Luis Potosí Valley (López-Álvarez et al. 2013) and in the Río Valles Basin (RVB) (López-Álvarez et al. 2015 ) to include water quality as a component and not as a subcomponent of the environment (Table I), because in Mexico groundwater and surface water present levels of natural and/or anthropogenic contamination.

TABLE I. KEY COMPONENTS OF THE WATER POVERTY INDEX (WPI) (adapted from Lawrence et al. 2002)

\begin{tabular}{|c|c|c|}
\hline WPI Component & Definition & - Sub-components \\
\hline Resource (R) & $\begin{array}{l}\text { Physical availability of surface and groundwater, } \\
\text { considering its use and water balance }\end{array}$ & $\begin{array}{l}\text { - Surface water } \\
\text { - Groundwater } \\
\text { - Volume used }\end{array}$ \\
\hline Access (A) & Level of access to safe water for human use & $\begin{array}{l}\text { - } \% \text { of the population with access to drinking water } \\
\text { - } \% \text { of population with access to water treatment } \\
\text { - } \% \text { of agricultural land with access to irrigation }\end{array}$ \\
\hline Capacity (C) & Efficacy of the population's capacity to manage water & $\begin{array}{l}\text { - Income } \\
\text { - Mortality rate of children under } 5 \text { years } \\
\text { - Education index } \\
\text { - Gini coefficient }\end{array}$ \\
\hline Usage (U) & $\begin{array}{l}\text { Ways in which water is used for different purposes, } \\
\text { including domestic, agricultural and industrial uses }\end{array}$ & $\begin{array}{l}\text { - Domestic water use, liters per day } \\
\text { - Percentage of water used for agriculture, adjusted } \\
\text { based on the sector's contribution to the GDP }\end{array}$ \\
\hline Environment (E) & Evaluation of environmental integrity related to water & $\begin{array}{l}\text { - NDVI } \\
\text { - SWI }\end{array}$ \\
\hline Water quality (Q) & Evaluation of water quality for human use & - Surface and groundwater quality data \\
\hline
\end{tabular}

GDP: gross domestic product, NDVI:= normalized differential vegetation index, SWI: soil wetness index 
In both cases, WPI has proved to be a relevant tool for identifying components with deficiencies and how water availability is affected (Table I).

\section{DEVELOPMENT OF THE WATER POVERTY INDEX}

In San Luis Potosí, the WPI was first applied in 2013 to the valley of the same name, which is located in a semi-arid zone with a $92 \%$ dependency on groundwater. The capital city is located within this valley, which concentrates $40 \%$ (1 034400 inhabitants) of the state's total population and is its most important industrial area.

The water resource is scarce and its management has not been adequate, resulting in a WPI score of 46 (López-Álvarez et al. 2013). The WPI was also evaluated for the RVB, which, unlike the previous case has a semi-tropical climate, and the main water source is of superficial origin $(98 \%)$.

In the RVB population is dispersed, which limits its access to services such as piped water in both quantity and quality, and its main economic activity is agriculture. These conditions combined with poor water management led to a result of 59 points, despite having an abundant water resource (López-Álvarez et al. 2015).

It should be noted that the WPI was applied in 140 countries by Lawrence et al. (2002).

The mathematical structure of the WPI is expressed as follows:

$I P A_{i}=\frac{\sum_{i=1}^{N} w_{X i} X_{i}}{\sum_{i=1}^{N} w_{X i}}$

where $W P I_{\mathrm{i}}$ is the WPI for a particular region and is the weighted sum of the components divided between the sum of the component weights, and $w_{\mathrm{Xi}}$ is the weight applied to each component $X_{\mathrm{i}}$. The definition and structure of the six components, resources (R), access $(A)$, use $(U)$, capacity $(C)$, environment $(E)$, and water quality (Q) is shown in tables I and II. The developed expression of equation (1) is presented in equation (2):

$$
I P A_{i}=\frac{w_{r} R+w_{a} A+w_{c} C+w_{u} U+w_{e} E+w_{q} Q}{w_{r}+w_{a}+w_{c}+w_{u}+w_{e}+w_{q}}
$$

The results are plotted in a polygon where the edges represent $100 \%$ of each component; when
TABLE II. WATER POVERTY INDEX (WPI) VALUES OBTAINED FOR EACH COMPONENT FOR THE BARRIL AQUIFER

\begin{tabular}{lccc}
\hline Component & Score & $w$ & WPI \\
\hline Resource & 0.25 & 30 & \\
Quality & 0.37 & 20 & \\
Use & 0.19 & 20 & 27 \\
Access & 0.21 & 10 & \\
Capacity & 0.43 & 10 & \\
Environment & 0.21 & 10 & \\
\hline
\end{tabular}

normalized, the maximum is 1 , while the center of the polygon is 0 . In an ideal case, when all the WPI components reach values of 1 a hexagon is formed.

In order to make comparisons between different study areas, the resulting value of the weighted sum is divided by the sum of the weights (equation 2). The weights have an influence on the WPI, expressed in effective weights. The effective weight $W_{\text {xi }}$ can be calculated for each component according to equation 3 (Ramos 2002):

$W x_{i}=\frac{X r_{i}^{*} X w_{i}}{\sum_{i=1}^{N} W_{i}}$

where $X_{\mathrm{ri}}$ and $X_{\mathrm{wi}}$ are the scores for each component $X_{\mathrm{i}}$ and their theoretical weights, and $W_{\mathrm{i}}$ is the sum of theoretical weights.

\section{Resources (R)}

The geometry of the BA is irregular and of varied dimensions, which difficult the presence of large lithologic units that function as aquifers (CONAGUA 2002). It is constituted mainly by sandblasts and low-cemented conglomerates, in addition to alluvial material (CONAGUA 2015).

This aquifer has an annual volume concession of $21.22 \mathrm{Mm}^{3}$, according to the public registry of water rights. The aquifer represents $99 \%$ of the population's water supply sources. The remaining $1 \%$ of the water is provided by small catchments, mainly the El Eucalipto dam, that altogether add $0.25 \mathrm{Mm}^{3}$ of water, which is used for irrigation purposes. The groundwater balance indicates a deficit of 304.67 $\mathrm{Mm}^{3} / \mathrm{yr}$, which shows a null recharge of the aquifer (Rizo-Fernández 2015).

The subcomponents of this component are surface water $(A s f)$ and groundwater $(A g w)$. The weight assigned to each subcomponent is related to the percentage of use, as can be seen in the following mathematical expression: 
$R=0.01 A s f+0.99 A g w$

$\operatorname{Asf}\left(\mathrm{Mm}^{3}\right)=\frac{\text { StoredVol }}{\text { AnnualPrecipitationVol }}$

$\operatorname{Agw}\left(\mathrm{Mm}^{3}\right)=\frac{\text { Recharge }- \text { Extraction }}{2 \text { Extraction }}$

\section{Access (A)}

Seventy-two percent of the total population of the municipality is located in the municipal seat, which is not the major population center, with 730 inhabitants and 198 homes. The town of Illescas has 1727 inhabitants and 653 houses, while Jesús María has 1979 inhabitants in 517 houses (INEGI 2010) (Fig. 1).

The 2011 socio-demographic survey reports that the percentage of housing with piped water increased to $42.4 \%$ (INEGI 2011). Ninety-six percent (3.1 $\mathrm{Mm}^{3} / \mathrm{yr}$ ) of the water distributed to the population originates from 22 deep wells (Rizo-Fernández 2015).

In the case of the municipal seat, $80 \%$ of the homes have a drainage network; however, untreated sewage is discharged within $50 \mathrm{~m}$ of the urban area (PDM 2009), which occurs in other locations throughout the municipality that do not have a drainage network, nor a treatment system.

The statistical yearbook of San Luis Potosí reports that the wastewater of the municipality of SD is deposited without treatment in lakes (INEGI 2014), which worsens the fact that water resources receive no treatment.

While the region's main economic activity is agriculture, access to water for agricultural irrigation benefits only $4 \%$ of the arable land (2600 ha) despite the fact that seasonal agriculture is the activity that demands the largest volume of water from the aquifer (INEGI 2007).

This component takes into account the percentage of population that has access to safe water $\left(A_{\text {ap }}\right)$ for their basic needs, the percentage of water that undergoes sanitation $\left(A_{\mathrm{t}}\right)$, and agriculture with irrigation $\left(A_{\mathrm{i}}\right)$. The expression that defines this component is:

$A=0.4 A_{a p}+0.1 A_{i}+0.5 A_{i}$

The weight allocation for the subcomponents was obtained through weight analysis (Ramos 2002).

\section{Capacity (C)}

The capacity component is based on the human development index (HDI), considering socio- economic variables that influence access and water quality. In Mexico, the HDI has been adjusted for the municipal level in terms of income, among others (PNUD/México 2014).

Another consideration that should be observed for the Mexican case is that, since there is no local per capita gross domestic product (GDP), net per capita income per household obtained from the National Survey is used (INEGI 2007).

One of the main demographic characteristics of thr SD municipality is its population spread, with only 2.77 inhabitants per square kilometer. From 1995 to 2010, the population declined on average by $10 \%$ (INEGI 2010), but in 2005 it fell by $20 \%$; by 2010 , the municipality was ranked with a high rate of emigration to the United States.

Although $67.2 \%$ of the population receives its income from the agricultural sector (SEDESORE 2015), remittances represent another source of income in $18 \%$ of the 565 homes in the municipality. In terms of education, the population reaches 5.66 years of schooling, and $70.67 \%$ of the population over 15 years of age has not concluded basic education.

This shows a condition of marginalization and low economic welfare. Seventy-one percent of the population does not have a minimum monthly income to meet food, education, health, housing, transportation, and recreation needs.

The capacity component is made up of the income index $\left(I_{\mathrm{i}}\right)$, the under-five mortality rate $\left(M_{\mathrm{i}}\right)$, the education index $\left(I_{\mathrm{e}}\right)$, and the Gini coefficient $\left(C_{\mathrm{G}}\right)$. It is evaluated through the expression:

$C=0.4 I_{i}+0.0 M_{i}+0.4 I_{e}+0.2 C_{G}$

The weight assignment for the subcomponents was obtained by weight analysis (Ramos 2002).

\section{Use (U)}

The main uses of water in the BA are $95 \%(20.16$ $\left.\mathrm{Mm}^{3}\right)$ agricultural and $5 \%\left(1.06 \mathrm{Mm}^{3}\right)$ domestic, where the latter consists in supplying drinking water to the population, ranging from 100 to 250 liters/ inhabitant/day (Rizo-Fernández 2015).

This component takes into account three subcomponents: water for domestic use $\left(U_{\mathrm{d}}\right)$, water for industrial use $\left(U_{\mathrm{i}}\right)$, and water for agricultural use $\left(U_{\mathrm{a}}\right)$, and is determined with the following equation:

$$
U=0.05 U_{d}+0.0 U_{i}+0.5 U_{a}
$$



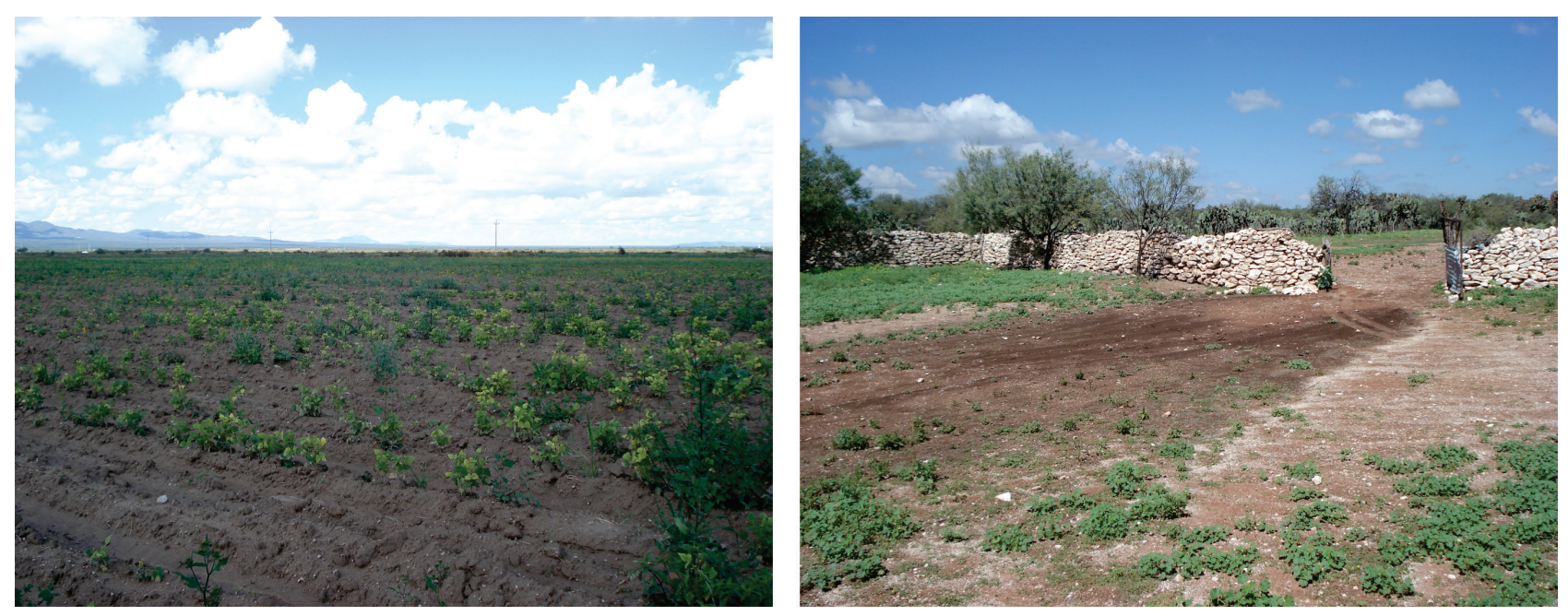

Fig. 3. Agricultural areas in Santo Domingo, San Luis Potosi, Mexico

There is no significant industrial activity in SD; therefore, it does not represent a subcomponent of the evaluation. The weight assigned to the subcomponents is based on the percentage of groundwater use in the BA.

\section{Environment (E)}

The condition of aridity and the type of vegetation ( $84 \%$ scrub and $3 \%$ grass) are natural characteristics of the area; however, aspects such as urban growth and the socioeconomic characteristics of the population have modified natural vegetation.

In the same sense, and as mentioned above, a large percentage of the territory is not suitable for agriculture (Fig. 3), which has contained the growth of this activity, barely reaching an area of 2600 ha (COTAS 2007). Between 1976 and 2000, the temporary agricultural area grew by 2 ha per year.

In the municipality of SD, cyclic crops such as beans and forage oats predominate. In the first case, it was reported that the 22900 ha planted (750 irrigation and 22150 temporary), only 16 255 ha were harvested (750 irrigation and 15505 temporary). The beans represented a volume of 3560 tons, whose value reached 2.09 million dollars (890 thousand dollars of irrigation and 1.2 million dollars of temporary), while forage oats generated 30 thousand tons with a value of 22500 thousand pesos (INEGI 2014).

Therefore, in terms of production, temporary agriculture is the most profitable, but entails a greater risk to the producer by the percentage obtained from it. Although rainfed agriculture reduces the pressure on groundwater, current climatic variations have rendered it much more vulnerable.
Climate is an influential factor in the vegetation cover. In the studied region, low rainfall (Fig. 4) and high evapotranspiration contribute to erosion and drought. Soil moisture is a key element in the agricultural activity. For that reason, the soil wetness index (SWI) as a marker of drought was applied to evaluate the environment component.

The SWI was obtained using techniques of remote perception in 2001 and 2011, both in the months of April and October, with the purpose of comparing soil moisture in two seasons of the year, considering April as the dry month and October the wet month.

The SWI considers the normalized differential vegetation index (NDVI) and soil surface temperature (Mallick et al., 2009).

$S W I_{i}=\frac{\left(T \max _{i}-T S_{i}\right)}{\left(T \max _{i}-T \min _{i}\right)}$

where $T s_{\mathrm{i}}$ is the surface temperature of the soil, $\operatorname{Tmax}_{\mathrm{i}}$ the maximum soil temperature, and $\operatorname{Tmin}_{\mathrm{i}}$ the minimum soil temperature.

The resulting SWI considers a scale of 0 to 1 , where 0 means low soil moisture and 1 is high soil moisture. For values close to zero, erosion and drought are increasing, with an impact on rainfed agriculture.

The SWI was measured using Lansat-TM5 from two satellite images views that cover the municipality of SD, because the temporal resolution of the satellite does not cover the entire area of study.

\section{Quality (Q)}

Water quality is affected by human activities such as untreated sewage disposal, municipal waste, and industrial and agricultural production, to name a few; 


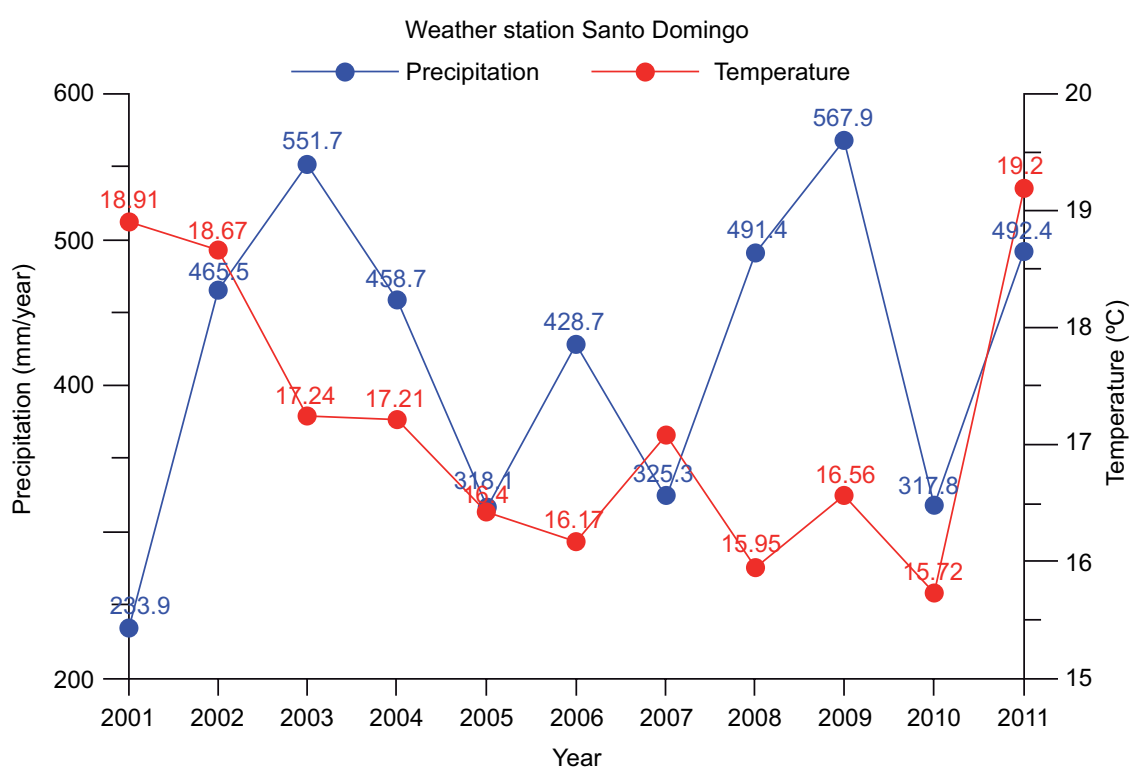

Fig. 4. (a) Average annual precipitation and (b) average annual temperature during the period from 2001 to 2011 reported in the Santo Domingo, San Luis Potosí, Mexico, weather station

however, there are components inherent to the natural environment from which water is extracted.

In the case of the BA's groundwater, for its infiltration process, extreme temperatures that produce high evaporation and an evolutionary process through the geological formations, the groundwater is enriched with minerals that give it a certain chemical composition and therefore a certain type of quality (Fig. 5). In the case study, the quality component was evaluated for human and agricultural consumption.
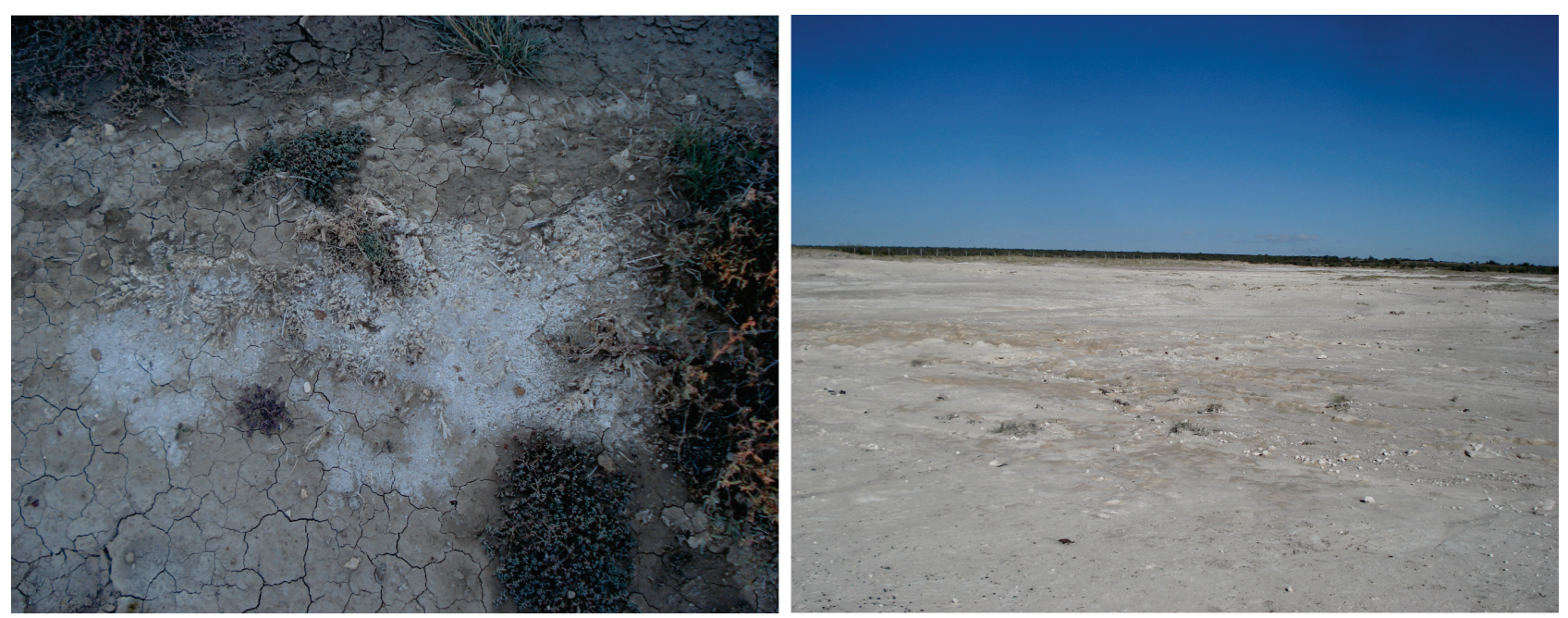

The chemical characteristics of the water that determine the quality for human consumption are based on the reference levels of Official Mexican Standard 127 (SSA 2000) through the Water Quality Index (WQI).

The WQI is a numerical evaluation of the concentrations of chemical parameters analyzed with multiplicative techniques and weighted with the assignment of a specific weight obtained from a geometric mean (Brown and McCclelland 1973). Its expression is defined in equation 9:

Fig. 5. Presence of salts in soils, as a result of high evaporation 
$W Q I=k \frac{\sum C_{i} P_{i}}{\sum P_{i}}$

where $C_{\mathrm{i}}$ is the percentage value assigned to the parameters due to their concentration; $P_{\mathrm{i}}$ is the weight assigned to each parameter, and $k$ is the constant that takes the following values: 1 for clear waters without apparent contamination; 0.75 for clear water with slight color, foam, and slight apparent turbidity not natural; 0.50 for waters with the appearance of being contaminated, and 0.25 for sewage with fermentations and odors. Altogether, water is evaluated on a scale of 0 to 1 , where 1 represents excellent quality and values less than 0.5 represent serious pollution problems.

On the other hand, water quality for agricultural use is commonly evaluated from the Wilcox diagram (Ayers and Westcot 1985). The construction of the diagram considers the electrical conductivity (EC) and the sodium adsorption ratio (SAR) (Richards 1954) for each of the samples (equation 10).

$$
S A R=\frac{N a^{+}}{\sqrt{\frac{C a^{2+}+M g^{2+}}{2}}}
$$

Groundwater can be grouped according to its sodium content in percent $(\mathrm{Na} \%)$, considered excellent for use in agricultural irrigation when it has values lower than $20 \%$, good with values of 20-40 $\%$, admissible with values of $40-60 \%$, doubtful with values of $60-80 \%$, and not adequate when values are higher than $80 \%$ (Wilcox 1956).

In this work, the following expression was developed to obtain the groundwater quality component, taking into account that this is the main source in the study area. Considering both the WQI and the SAR, the equation that defines the quality component is:

$Q=0.05 Q_{A h}+0.95 Q_{A g}$

where $Q_{\mathrm{Ah}}$ is the drinking-water quality and $Q_{\mathrm{Ag}}$ is the water quality for agricultural use. The weight factors (0.05 and 0.95) used in this component were allocated according to the percentage of groundwater use.

\section{RESULTS AND DISCUSSION}

\section{Resource}

The groundwater of the BA represents practically the only source of water for the population of SD.
The resource has been limited by natural conditions, affecting its recharge, storage, and quality.

In general, it is possible to identify the factors that intervene in the availability of the resource: natural and anthropogenic factors. Rainfall is scarce and evapotranspiration reaches close values to this, the availability of water for the recharge of the aquifer is almost null. In addition, due to the geometry of the aquifer, the hydraulic connectivity of materials favorable to water storage in the subsoil is restricted (Rizo-Fernández 2015). In the case of non-natural (anthropogenic) factors, this is due to poor and misguided management that affects access to water.

For example, water supply to the population should be a priority; however, $95 \%$ of groundwater is used in agriculture, whose yields and profitability are low (Rizo-Fernández 2015). Due to its chemical characteristics, water may be subjected to a type of treatment that makes it suitable for human consumption, which does not occur now.

The assessment of the resource resulted in a value of 0.25 , which reflects the adverse natural conditions of the study area.

\section{Access}

Access to public services such as potable water and sewerage is an indicator of the wellness of families, and contributes to the reduction of mortality and morbidity among the population under five-years old, by reducing the transmission of diseases such as viral hepatitis, typhoid fever, cholera, dysentery, and other causes of diarrhea (CONAGUA 2011).

On the other hand, it is also important to ensure access to water for agricultural productivity, since this contributes to increasing incomes and decreasing food costs for all consumers (FAO 2001).

The access component registered a value of 0.21 because less than half of the population has piped water and there is no infrastructure for wastewater sanitation, a condition due in part to the dispersion of population.

\section{Capacity}

For the capacity component, it is important to highlight that in 2010,69.3\% of the population of the municipality of SD lived in poverty conditions (SEDESOL 2014). The $I_{\mathrm{i}}$ calculated for the studied population was 0.43 , while the $I_{\mathrm{e}}$ was 0.79 and the $C_{\mathrm{G}}$ was 0.37 (CONEVAL 2010).

One element in favor of this zone is that in the reports there is no evidence of infant mortality. The resulting value for the capacity component was 0.43 .

This value may be a reflection of low income as a 
result of poor performance. This value does not fully reflect the real condition of economic welfare. The poverty condition is notorious and generalized among the population, and hence the $C_{\mathrm{G}}$ is 0.37 .

\section{Use}

The water extracted from the aquifer is used mostly in agricultural irrigation. Agricultural production is basically intended for self-consumption (CEFIM 2012). On the other hand, its value has little influence on the state's GDP and the regional economy.

Also, public services, such as water for domestic use, are concentrated in the municipal seat of SD, leaving the rest of the localities with a poor supply. In addition, due to the chemical characteristics of groundwater, it needs some type of treatment to be suitable for agricultural use; however, this does not currently occur.

The score obtained for the use component is a normalized value of 0.19 , which reflects the socioeconomic situation of the study area.

\section{Environment}

The highest concentration of droughts occurs in the highland area of the state of San Luis Potosí, and SD is one of the municipalities with the highest recurrence between 1960 and 2010. The type of droughts that characterize this region is meteorological (Pérez-Baltazar 2012). As a result, agricultural activity present in the region shows a high vulnerability. On the one hand, because the type of agriculture that apparently has rendered significant production volumes depends on climatic conditions that increasingly show less predictable patterns. And on the other hand, the less dynamic part, with lower risks for producers, requires an over exploited source, with strong pollution problems and subject to discretionary management.

The consequences range from delayed planting, crop damage, partial or total crop loss, area reduction, increased input costs, loss of plant cover, erosion, and loss of soil with the loss of ecosystem functions that this implies, in addition to the impacts that this generates for both producers and consumers. In this sense, exposure and vulnerability to phenomena such as drought are the result of biased development processes.

After evaluating the SWI for the BA, for the month of April 2001 and 2011, average values of 0.38 and 0.49 were obtained, respectively. For the month of October 2001 and 2011, average values of 0.28 and 0.35 were obtained, respectively. The SWI distribution for SD in the two evaluated periods is presented below (Fig. 6).
In general, it is observed that the soil moisture measured with the SWI in the BA is low, in the range of 0 to 0.4 , predominantly in the two seasons (dry and wet) of the period evaluated. The value obtained for the SWI average was 0.21 points, which is directly related to the soil moisture.

\section{Quality}

Regarding water for human consumption, the BA groundwater exhibits major issues of natural contamination by arsenic, fluorine, manganese, and other elements such as nitrates $\left(\mathrm{NO}_{3}^{-} \mathrm{NO}_{3}^{-}\right)$and total dissolved solids (Rizo-Fernández 2015) that exceed the maximum allowable limits established by NOM127-SSA1 (SSA 2000). The resulting WQI was 0.35. The water of the aquifer of SD is considered strongly contaminated, therefore it is not suitable for human consumption.

Concerning SAR and $\mathrm{CE}$, the value obtained was 0.47 , which reflects the low quality of the water used for agriculture, since it presents high values in sodicity and salinity (Rizo-Fernández 2015). Overall, the resulting value for the quality component was 0.37 .

In summary, the score obtained for each component and its weight is presented in table II, as well as the overall result of the WPI for the BA in Santo Domingo, whose value was 27 points plotted in the resulting polygon (Fig. 7).

The lowest components of the WPI of the BA are use, access, environment, and resource, followed by quality and capacity; however, in general the values obtained are less than 0.5 .

\section{CONCLUSIONS}

The BA presents unfavorable conditions in all its components, due to its climatic, geological, and hydrological conditions, which yield a WPI of 27.

The water extracted from the BA is used predominantly in agriculture with low yields, resulting in a very low use component value of 19 , while the resource and environment components resulted in values of 25 .

Both reflect how the hydrogeological and climatic characteristics determine the physical availability of the resource with direct effects on the type of vegetation and the development of agriculture. Thus, economic development is also diminished, since farmers do not have access to water in sufficient quantity or quality, which results in decreasing crop yields and consequently economic gains. 

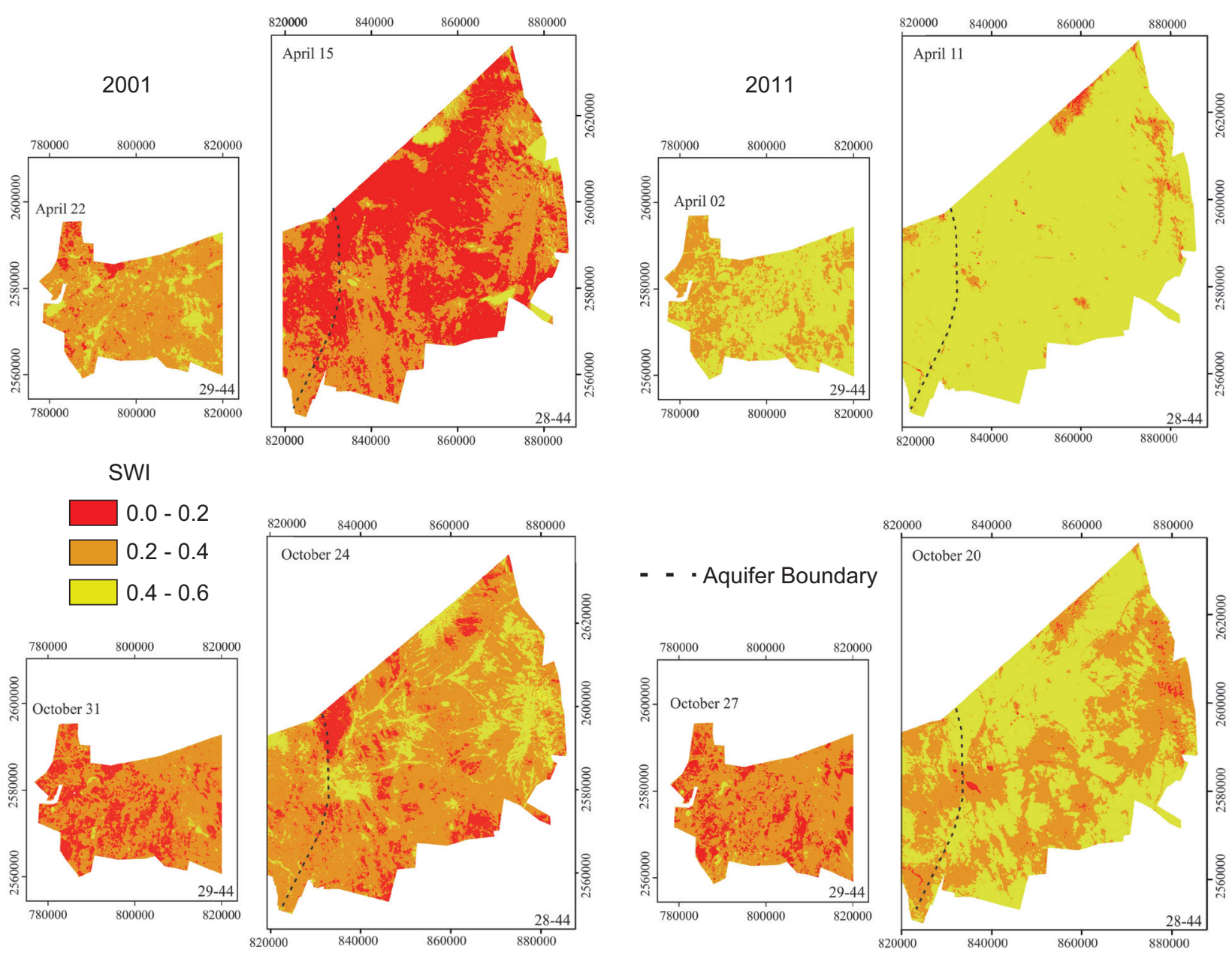

Fig. 6. Soil wetness index (SWI) for the months of April and October 2001 and 2011, for Santo Domingo, San Luis Potosí, Mexico

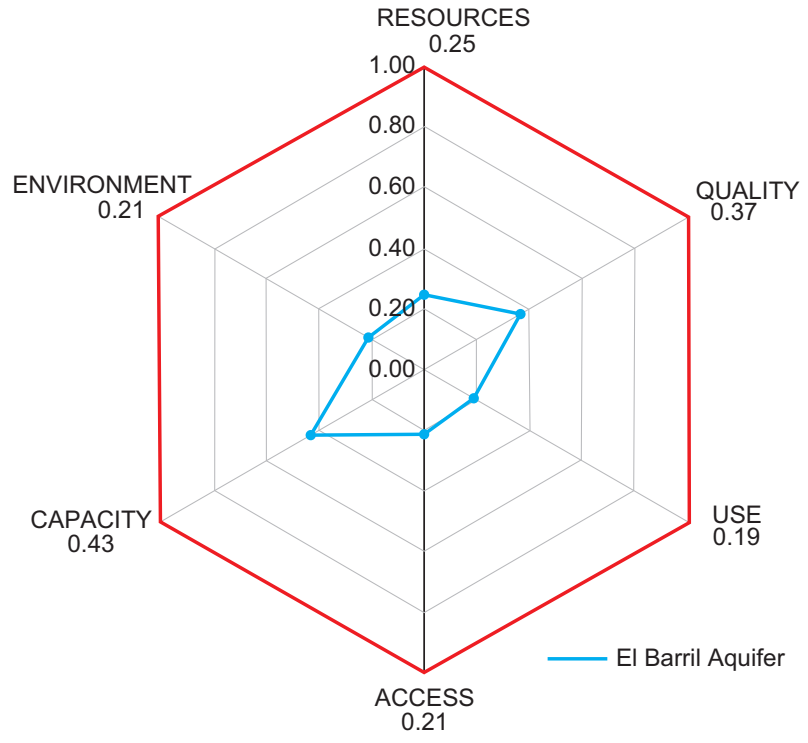

Fig. 7. Hexagon of the standard water poverty index of the Barril Aquifer
In the same regard, the quality component obtained a score of 47, with a great influence of human activities. However, the geology of the region combined with evaporation processes produce low quality of the groundwater, exceeding the maximum permissible limits established by NOM-127-SSA1 (SSA 2000), mainly limiting its use for human consumption. This condition highlights the degradation of natural resources, as a result of economic activities, even threatening human welfare.

Concerning the access and capacity components, which obtained scores of 21 and 43, respectively, they can be associated to the sociodemographic characteristics of the population of SD. It has been recognized that the lack of public services such as drinking water, sanitation systems, health and education is almost always linked to poverty and marginalization and, in this case, it is homogeneously distributed in the population. 
On the other hand, the lack of these services also has an important impact on environmental deterioration and, consequently, on the deterioration of water resources.

\section{REFERENCES}

Ayers S. and Westcot D. (1985). Water quality for agriculture. Food and Agriculture Organization of the United Nations, Rome, Italy, $174 \mathrm{pp}$.

Brown R. y McClelland N. (1973). Water Quality Index. Application in the Kansas River Basin. US-EPA Report. EPA Region VII. Conf. Water Poll. Fed. Cleveland, Ohio, $76 \mathrm{pp}$.

CEFIM (2012). Monografías de los municipios de México: Santo Domingo. Coordinación Estatal para Fortalecimiento Institucional de los Municipios, San Luis Potosí, Mexico, $32 \mathrm{pp}$.

CONAGUA (2002). Determinación de la disponibilidad de agua en el acuífero "El Barril", Estado de San Luis Potosí. Subgerencia de Evaluación y Modelación Hidrogeológica, Comisión Nacional del Agua, Distrito Federal, Mexico, 9 pp.

CONAGUA (2011). Estadísticas del agua en México. Capítulo 6: Agua, salud y medio ambiente. Comisión Nacional del Agua [on line]. http://www.conagua.gob. $\mathrm{mx} / \mathrm{CONAGUA07/Publicaciones/Publicaciones/SGP-}$ 1-11-EAM2011.PDF 11/05/18

CONAGUA (2015). Actualización de la disponibilidad media anual de agua en el acuífero El Barril (2402), Estado de San Luis Potosí. Subdirección General Técnica, Gerencia de Aguas Subterráneas, Comisión Nacional del Agua [on line]. https://www.gob.mx/ cms/uploads/attachment/file/104264/DR_2402.pdf $11 / 05 / 18$

CONEVAL (2010). Medición de la pobreza. Indicadores de cohesión social, según municipio. México 2010. Consejo Nacional de Evaluación de la Política de Desarrollo Social [on line]. http://www.coneval.gob. $\mathrm{mx} /$ Medicion/Paginas/Cohesion_Social.aspx 11/01/15

CONEVAL (2013). Informe de pobreza y evaluación. San Luis Potosí, 2012-2013. Informe. Consejo Nacional de Evaluación de la Política de Desarrollo Social, Distrito Federal, Mexico, $89 \mathrm{pp}$.

COTAS (2007). Plan de manejo integral del acuífero de El Barril. Comité Técnico de Agujas Subterráneas, San Luis Potosí, Mexico, 68 pp.

FAO (2001). Irrigation water management: irrigation methods. Training manual no. 5. Food and Agriculture Organization of the United Nations [on line]. http:// www.fao.org/tempref/agl/AGLW/fwm/Manual5.pdf1 $11 / 05 / 18$
INEGI (2007). Censo agropecuario. VIII Censo agrícola, ganadero y forestal. Instituto Nacional de Estadística y Geografía, Distrito Federal, Mexico.

INEGI (2009). Prontuario de información geográfica municipal de los Estados Unidos Mexicanos. Santo Domingo, San Luis Potosí. Clave geoestadística 24033. Instituto Nacional de Estadística y Geografía [on line]. http://www3.inegi.org.mx/contenidos/app/mexicocifras/datos_geograficos/24/24033.pdf 11/05/18

INEGI (2010). Censo de población y vivienda 2010. Instituto Nacional de Estadística y Geografía, Distrito Federal, Mexico.

INEGI (2011). Panorama sociodemográfico para 2011. Instituto Nacional de Estadística y Geografía [on line]. http://internet.contenidos.inegi.org. $\mathrm{mx} /$ contenidos/Productos/prod_serv/contenidos/espanol/ bvinegi/productos/censos/poblacion/2010/panora_socio/702825001897.pdf 11/05/18

INEGI (2014). Anuario estadístico y geográfico de San Luis Potosí 2014. Instituto Nacional de Estadística y Geografía [on line]. http://internet.contenidos.inegi. org.mx/contenidos/productos/prod_serv/contenidos/ espanol/bvinegi/productos/anuario_14/702825065416. pdf 26/01/19

Lawrence P., Meigh J. and Sullivan C. (2002). The water poverty index: An international comparison. Keele Economics Research Papers [on line]. http://citeseerx. ist.psu.edu/viewdoc/download?doi=10.1.1.13.2349\&r $\mathrm{ep}=\mathrm{rep} 1 \&$ type $=$ pdf $11 / 05 / 18$

López-Álvarez B., Ramos-Leal J., Santacruz-De León G., Morán-Ramírez J., Carranco-Lozada S., NoyolaMedrano C. and Pineda-Martínez L. (2013), Cálculo del índice de pobreza del agua en zonas semiáridas: caso valle de San Luis Potosí. Rev. Int. Contam. Ambie. 29 (4), 249-260.

López-Álvarez B., Santacruz-de León G., Ramos-Leal J.A. and Morán-Ramírez J. (2015) Water poverty index in subtropical zones: The case of Huasteca Potosina, Mexico. Rev. Int. Contam. Ambie. 31 (2), 173-184.

Mallick K., Bhattacharya B.K. and Patel N.K. (2009). Estimating volumetric surface mois-ture content for cropped soils using a Soil Wetness Index based on surface temperature and NDVI. Agr. Forest Meteorol. 149 (8), 1327-1342. DOI: 10.1016/j.agrformet.2009.03.004 PDM (2009). Plan de Desarrollo Municipal 2009-2012. H. Ayuntamiento de Santo Domingo, 34 pp.

Pérez-Baltazar M.I. (2012). Análisis espacio-temporal de las amenazas naturales, la ocurrencia de desastres y su relación con el Índice de Desarrollo Humano en el Estado de San Luis Potosí, México 1960-2010. Tesis de Licenciatura. Coordinación de Ciencias Sociales y Humanidades, Universidad Autónoma de San Luis Potosí, San Luis Potosí, Mexico, 141 pp. 
Pineda-Martínez L.F., Carbajal N. and Medina-Roldán E. (2007). Regionalization and classification of bioclimatic zones in the central-northeastern region of Mexico using principal component analysis (PCA). Atmósfera 20 (2), 133-145.

PNUD-México (2014). Índice de desarrollo humano municipal en México: nueva metodología. Programa de las Naciones Unidas para el Desarrollo en México [on line]. http://www.mx.undp.org/content/dam/mexico/ docs/Publicaciones/PublicacionesReduccionPobreza/ InformesDesarrolloHumano/UNDP-MX-PovRedIDHmunicipalMexico-032014.pdf 11/05/18

Ramos J.A. (2002). Validación de mapas de vulnerabilidad acuífera e impacto ambiental: caso Río Turbio, Guanajuato. Tesis de doctorado. Instituto de Geofísica, Universidad Nacional Autónoma de México, 106 pp.

Rizo-Fernández Z. (2015). Cálculo del índice de pobreza del agua en el acuífero de Santo Domingo, S.L.P. Tesis de Maestría. División de Geociencias, Instituto Potosino de Investigación Científica y Tecnológica, San Luis Potosí, Mexico, 111 pp.

SAGARPA (2013). El problema de la desertificación, Revista claridades agropecuarias. Secretaría de Agricultura, Ganadería, Desarrollo Rural, Pesca y Alimentación [on line]. http://www.infoaserca.gob.mx/ claridades/revistas/238/ca238-30.pdf 11/05/18

SEDESOL (2014). Informe anual sobre la situación de pobreza y rezago social. Santo Domingo, San Luis Potosí. Secretaría de Desarrollo Social [on line]. http://www.sedesol.gob.mx/work/models/SEDESOL/ Informes_pobreza/2014/Municipios/San_Luis_Potosi/ San_Luis_Potosi_033.pdf 11/05/18
SEDESORE (2015). Plan Municipal de Desarrollo 20152018. Santo Domingo. Secretaría de Desarrollo Social y Regional http://www.transparenciamunicipalslp.gob. $\mathrm{mx} /$ Transparencia/Municipios//_SANTO\%20DOMINGO/Art\%C3\%ADculo\%2020.\%20fracc.\%20II/ PLAN\%20MUNICIPAL\%20DE\%20DESARROLLO/ planmdes\%20stodomingo.pdf 26/01/19

SSA (2000). Norma Oficial Mexicana NOM-127SSA1-1994. Salud ambiental. Agua para uso y consumo humano. Límites permisibles de calidad y tratamientos a que debe someterse el agua para su potabilización. Diario Oficial de la Federación, 22 de noviembre [on line]. http://www.salud.gob.mx/ unidades/cdi/nom/127ssa14.html 26/01/19

Sullivan C.A., Meigh J.R., Giacomello A.M., Fediw T., Lawrence P., Samad M., Mlote S., Hutton C., Alan J.A., Schulze R.E., Dlamini D.J.M., Cosgrove W., Delli Priscoli J., Gleick P., Smouth I. Cobbing J., Calow R., Hunt C., Hussain A., Acreman M.C., King J., Malomo S., Tate E. L., O'Regan D., Milner S. and Steyl I. (2003). The Water Poverty Index: Development and application at the community scale. Nat. Resour. Forum 17, 189-199. DOI: 10.1111/1477-8947.00054

Richards A. 1954. Diagnóstico y rehabilitación de suelos salinos y sódicos. Editorial Limusa, Distrito Federal, Mexico, 172 pp.

Wilcox L.V., 1955. Circular 969. Classification and Use of irrigation waters. United States Department of Agriculture, Washington, D.C., 19 pp. 